\title{
HABEAS CORPUS: INTERSTATE DETAINERS AND IN PERSONAM JURISDICTION
}

Presently, a prisoner confined in one state subject to a detainer ${ }^{1}$ issued by another state cannot attack the detainer's validity and its present effects on the prisoner's confinement in a single habeas corpus proceeding. Rather, the prisoner must petition a district court in the demanding state for a determination of the validity of the detainer, and another district court in the confining state for relief from the present effects of the detainer. The inability of a district court in either state to adjudicate both claims simultaneously stems from its lack of in personam jurisdiction over the prisoner's custodian in the other state. After outlining the history of the current procedure, this Comment will examine means by which a single court could adjudicate all claims relating to a foreign detainer when desirable to do so.

\section{Foreign Detainers: The Problem Stated}

In 1968, the Supreme Court expanded the scope of habeas corpus in Peyton v. Rowe ${ }^{2}$ by allowing a prisoner confined in one state subject to a detainer issued by another state to attack collaterally the validity of the foreign detainer without having to complete beforehand the sentence imposed by the confining state. ${ }^{3}$ The result in Peyton was particularly consequential for a prisoner subject to a foreign detainer because of the likelihood that the

\footnotetext{
${ }^{1}$ A detainer, or hold order, is a warrant sent from one state to another to provide notification that a prisoner is wanted in the demanding state and to request that the confining state inform the demanding state of the prisoner's release date. The detainer need not rest upon a conviction, but may be based upon an indictment, information, arrest warrant, parole violator warrant, or the mere desire of the demanding state to question the prisoner. See Dauber, Reforming the Detainer System: A Case Study, 7 CRIM. L. Bull. 669, 670 (1971); Tuttle, Catch 2254: Federal Jurisdiction and Interstate Detainers, 32 U. PITr. L. Rev. 489, 491.(1971); Wexler \& Hershey, Criminal Detainers in a Nutshell, 7 CRIM. L. Bull. 753, 753 n.2 (1971); Note, Detainers and the Correctional Process, 1966 WASH. U.L.Q. 417.

2391 U.S. 54 (1968).

${ }^{3}$ More precisely, Peyton held that a prisoner serving consecutive sentences could bring a habeas action to challenge any one of them. Thus after Peyton, a prisoner could challenge a detainer based upon a conviction, but not a detainer based, for instance, upon an arrest warrant. Broadened possibilities for attacking a detainer were established subsequently in Braden v. 30th Judicial Circuit Court, 410 U.S. 484 (1973), and Nelson v. George, 399 U.S. 224 (1970). See text accompanying notes 8-22 infra.
} 
detainer would adversely affect the prisoner's current state of confinement. He might be held under maximum security, disallowed the privilege of assuming a trusteeship or another position of responsibility, denied parole, or refused consideration for rehabilitation programs. ${ }^{4}$

Although Peyton opened an avenue for redress of certain deleterious effects of the foreign detainer, the decision created a perplexing choice-of-forum problem: When subject to a detainer, should a prisoner petition for a writ of habeas corpus in a federal district court in the state in which he is confined or in the state that has issued the detainer? The controlling federal statute states that "[w]rits of habeas corpus may be granted by the Supreme Court, any justice thereof, the district courts and any circuit judge within their respective jurisdictions." In 1948, the phrase "within their respective jurisdictions" was interpreted in Ahrens $v$. Clark $^{6}$ as denying a district court subject matter jurisdiction to grant the writ unless the person in custody was within the territorial jurisdiction of the court. Territorial presence of the prisoner's custodian was deemed insufficient. ${ }^{7}$ Consequently, a district court in one state was regarded automatically as lacking habeas jurisdiction over a convict confined in another state.

On the other hand, even though the requirement of territoriality enabled the district court in the confining state to claim subject matter jurisdiction over the prisoner, the custodian

${ }^{4}$ Smith v. Hooey, 393 U.S. 374, 378 (1969); Word v. North Carolina, 406 F.2d 352, 354 (4th Cir. 1969); see Dauber, supra note 1, at 691-96; Schornhorst, Presentence Confinement and the Constitution: The Burial of Dead Time, 23 HAstings L.J. 1041, 1085-86 (1972); Tuttle, supra note I, at 491-93; Note, supra note 1, at 418-23.

A federal regulation proscribes a detainer's automatically barring parole consideration. 28 C.F.R. $\$ 2.33$ (e) (1975) provides: "The presence of a detainer is not of itself a valid reason for the denial of parole. It is recognized that where the prisoner appears to be a good parole risk, there may be distinct advantage in granting parole despite a detainer."

Despite the adverse effects on prisoners' confinement, detainers are easy to file and their legal justification is rarely examined. Detainers may serve as an effective means of punishing without first convicting: "Many detainers are apparently filed for punitive reasons; they are withdrawn shortly before the convict's release, having served their purpose by curtailing prison privileges and preventing parole. According to one estimate, as many as one half the detainers are never pursued by the requesting authority." Goldfarb \& Singer, Redressing Prisoners' Grievances, 39 Geo. Wash. L. Rev. 175, 229 n.345 (1970); see Dauber, supra note 1 (statistical study of detainers in Massachusetts); Tuttle, supra note 1, at 492; Note, supra note 1 , at 422-23.

528 U.S.C. § 2241 (a) (1970). The statutes governing habeas corpus generally are codified at 28 U.S.C. $\$ \$ 2241-55$ (1970).

${ }^{6} 335$ U.S. 188 (1948), criticized in Developments in the Law-Federal Habeas Corpus, 83 HaRv. L. Rev. 1038, 1162-65 (1970).

${ }^{7} 335$ U.S. at 190. 
in the state that issued the detainer might escape the reach of service of process. Thus, although a prisoner after Peyton was entitled to bring a habeas action to attack an out-of-state detainer, he was caught in a dilemma: In one of the two districts in which the writ could be sought, the court lacked subject matter jurisdiction; in the other, it lacked in personam jurisdiction over the custodian in the other state.

The fundamental unfairness of this situation was soon recognized by the courts. The 1969 case of George v. Nelson ${ }^{8}$ involved a California prisoner who petitioned for a writ of habeas corpus in a federal district court in California to attack the conviction underlying a North Carolina detainer. The Ninth Circuit solved the challenge to personal jurisdiction by declaring the California warden a proper respondent because he was not only the actual custodian but also an agent of North Carolina. ${ }^{9}$ The circuit court indicated that if the warden did not desire to defend the conviction, he could importune the appropriate North Carolina authorities to do so. ${ }^{10}$

The issue of the soundness of this approach was left in abeyance, however, when the Supreme Court affirmed the Ninth Circuit decision without reaching the question whether a state prisoner could test in the confining state the validity of the conviction underlying a foreign detainer. ${ }^{11}$ Because the prisoner challenged not only the conviction underlying the foreign detainer but also the present effect given the detainer by the California authorities, a matter that had not been presented to the California courts, the Court narrowly concluded that the prisoner had not exhausted available state remedies. ${ }^{12}$ Before seeking federal relief, the prisoner should have challenged in the California state court system any unfavorable treatment resulting from regard by California for the North Carolina detainer. Distinguishing the present effect of the detainer from its general validity, the Court affirmed the judgment of the circuit court insofar as it recognized jurisdiction in the district court to entertain the prisoner's claims regarding the impact of the detainer if

${ }^{8} 410$ F.2d 1179 (9th Cir. 1969), aff'd on other grounds, 399 U.S. 224 (1970).

9410 F.2d at 1181 .

${ }^{10} \mathrm{Id}$.

11399 U.S. 224 (1970). For sharp criticism of the Court's ruling in this case, see Wexler \& Hershey, supra note 1, at 776 (footnote omitted): "The default of the Supreme Court in George has perpetuated an intolerable jurisdictional situation, which will exist until the Court reconsiders Ahrens or until a clarification is provided by Congress or through the Supreme Court's legislative rule-making process."

12399 U.S. at 229; see 28 U.S.C. §§ 2254(b), (c) (1970). 
the prisoner chose to press those claims after exhausting his state remedies. ${ }^{13}$

The Ninth Circuit's approach was rejected in the 1969 case of Word $v$. North Carolina, ${ }^{14}$ in which the Fourth Circuit held that state prisoners confined in Virginia and subject to North Carolina detainers could attack the convictions underlying the detainers only in a habeas action in North Carolina. The Fourth Circuit suggested that a federal district court in Virginia would lack jurisdiction over the action because the confining warden in Virginia had no duty to defend the North Carolina detainers. ${ }^{15}$ The circuit court noted, however, that the district court in Virginia would have jurisdiction over attacks on the present effects of the foreign detainers. ${ }^{16}$

The 1973 Supreme Court decision in Braden v. 30th Judicial Circuit Court ${ }^{17}$ partially adopted the reasoning of Word and severely limited Ahrens. An Alabama state prisoner, subject to a Kentucky derainer based on a grand jury indictment, petitioned a federal district court in Kentucky for a writ of habeas corpus, after failing to obtain Kentucky state relief on his claim of denial of his constitutional right to a speedy trial. The federal district court held that the prisoner was denied a speedy trial and ordered the Kentucky authorities either to secure the prisoner for trial within sixty days or to dismiss the charges against him. ${ }^{18}$

13399 U.S. at $229-30$.

14406 F.2d 352 (4th Cir. 1969) (en banc).

${ }^{15} \mathrm{Id}$. at 357. Ahrens v. Clark, 335 U.S. 188 (1948), was declared noncontrolling. The court reasoned that subsequent cases had demonstrated that presence of the petitioner in the territorial jurisdiction of the court is not always required and that Ahrens was not decided in the context of multistate detainers. 406 F.2d at 358-61.

${ }^{16} 406$ F.2d at 357 n.6. The court qualified its holding further by indicating that under certain circumstances fairness might require that a district court in a confining state adjudicate claims concerning a conviction underlying a foreign detainer. Id. at 361 . Thus, the Fourth Circuit would probably not foreclose a prisoner's attacking in the state of his confinement the validity of a foreign detainer if no other forum would hear his claim. The Second Circuit has accepted the Word rationale that a district court in the demanding state is usually a more convenient forum than a district court in the confining state. United States ex rel. Meadows v. New York, 426 F.2d 1176, 1182 (2d Cir. 1970), cert. denied, 401 U.S. 941 (1971) (noting that the court in the confining state has concurrent jurisdiction), discussed in Comment, Towards a Solution of the Jurisdictional Problem in Multi-State Federal Habeas Corpus Actions Challenging Future Restraints, 1970 Utah L. Rev. 625. But see United States ex rel. Van Scoten v. Pennsylvania, 404 F.2d 767 (3d Cir. 1968); Ashley v. Washington, 394 F.2d 125 (9th Cir. 1968) (confiningstate court is proper forum).

${ }^{17} 410$ U.S. 484 (1973). For a discussion of this case within the post-Peyton context of interjurisdictional detainers, see Meyer \& Yackle, Collateral Challenges to Criminal Convictions, 21 U. KAN. L. Rev. 259, 283-87 (1973).

${ }^{18}$ Braden v. 30th Judicial Circuit Court, 454 F.2d 145, 146 (6th Cir. 1972), rev'd, 410 U.S. 484 (1973). 
The Sixth Circuit, holding that only a court in the confining state had jurisdiction to entertain the prisoner's habeas petition, reversed. ${ }^{19}$ The prisoner could not then proceed, however, in a district court in the state of his confinement, because the rule of that circuit was that a district court in the demanding state was the proper forum in which to file a petition for habeas. ${ }^{20}$ Thus, on review the Supreme Court could either expand the meaning of "within their respective jurisdictions" and vitiate the interpretation of Ahrens that had prevailed for twenty-five years, or deprive the prisoner of the only remaining forum in which he could seek relief. ${ }^{21}$ Selecting the first alternative, the Court reinterpreted the "within their respective jurisdictions" language of the federal habeas statute to require only that the court issuing the writ of habeas corpus possess in personam jurisdiction over the custodian to whom the writ was directed. ${ }^{22}$

After 1973, a state prisoner no longer faced the jurisdictional difficulties he might have confronted earlier. Subject to a foreign detainer, he had two options: attack the present impact of the detainer on his incarceration in a federal district court in the confining state under the Supreme Court's decision in George $v$. Nelson, or challenge the validity of the detainer in a federal district court of the demanding state under Braden. Unfortunately, however, the prisoner still was unable to utilize a single action to attack both the effect and the validity of the detainer.

In a subsequent Fourth Circuit case, Norris v. Georgia, ${ }^{23}$ a North Carolina prisoner petitioned a federal district court in North Carolina for a writ of habeas corpus, seeking dismissal of detainers lodged against him by Georgia and Louisiana on the ground of denial of his right to a speedy trial. The district court concluded that it had jurisdiction not only to consider the adverse impact on confinement of the detainers, but also to bar Georgia and Louisiana authorities from prosecuting petitioner on the charges underlying the detainers. ${ }^{24}$ This result was reached basically by interpreting Braden to say that a habeas corpus proceeding could be brought either in the district of confinement or in the district where the detainer was issued. ${ }^{25} \mathrm{On}$

${ }^{19} \mathrm{Id}$. at $145-48$.

${ }^{20}$ See id. at 146; May v. Georgia, 409 F.2d 203 (5th Cir. 1969).

${ }^{21}$ See 410 U.S. at 488.

$22 I d$. at 495.

${ }^{23} 522$ F.2d 1006 (4th Cir. 1975).

${ }^{24}$ Norris v. Georgia, 357 F. Supp. 1200, 1204 (W.D.N.C. 1973), aff'd in part, rev'd in part, 522 F.2d 1006 (4th Cir. 1975).

${ }^{25}$ An analysis of the relative convenience of each forum led the district court to conclude that North Carolina was the proper locale. Id. 
appeal, the circuit court reversed the lower court's decision with respect to the jurisdiction of the North Carolina district court over claims relating to the validity of the detainers. The court reasoned that the district court was without in personam jurisdiction to challenge the validity of the underlying detainer because it lacked capacity, within its geographic boundaries, to enforce any order that might ensue. ${ }^{26}$

Thus, a prisoner presently subject to a foreign detainer remains in a quandary with regard to how he should attack the detainer. Pursuing only one of either the Nelson (impact) or Braden (validity) routes can result in no more than partial justice. Initially, suppose the prisoner attacks the validity of the detainer in the demanding district. Assuming that he receives a judgment vacating the detainer, he may have to pursue further legal action to have the decision recognized in the confining state to eliminate the detainer's effects on present confinement. Such action would be necessary if regular channels of communication between the demanding and confining authorities were lacking, or if, for whatever reason, the actual custodian, who is not under the jurisdiction of the district court in the demanding state, were to refuse or fail to take note of the prisoner's successful litigation in the demanding state. ${ }^{27}$ On the other hand, if the prisoner were to obtain relief in the confining state from the detainer's effects on his present confinement, the essential validity of the detainer would remain undisturbed. Thus, upon transfer to another custodian the deleterious effects might be reinstituted. ${ }^{28}$ Moreover, rarely does a prisoner attack the effects of a detainer without raising claims regarding its validity, except when merely contesting an irregularity in the process by which the confining state gives effect to the detainer. ${ }^{29}$

Considering the drawbacks of contesting only either the present effect or the validity of a foreign detainer, a prisoner desiring to attack a foreign detainer might do well to petition both the demanding and the confining states. But beyond the unfortunate waste of judicial resources, this procedure is techni-

${ }^{26} 522 \mathrm{~F} .2 \mathrm{~d}$ at 1010 . The court indicated that although the immediate custodian is an agent of the demanding state for the purpose of establishing subject matter jurisdiction, he is not an agent for the service of process incident to in personam jurisdiction. Id. at 1010-11.

${ }^{27}$ See id. at 1016 n.3 (Winter, J., dissenting in part); cf. Craig v. Beto, 458 F.2d 1131,1134 (5th Cir. 1972).

${ }^{28}$ See Varallo v. Ohio, 312 F. Supp. 45, 46 (E.D. Tex. 1970).

${ }^{29}$ Norris v. Georgia, 522 F.2d 1006, 1018 (4th Cir. 1975) (Winter, J., dissenting in part). 
cally unjustifiable. Why should the prisoner have to go to court twice when a successful attack on the validity of a detainer leaves no doubt that the continuing impact of the detainer is unlawful?

Underlying a prisoner's inability to attack a foreign detainer fully in a single action are the requirements for in personam jurisdiction imposed by the federal courts. When confronted with an action by a prisoner in one state who is subject to a detainer issued by another state, federal district courts in both states may possess subject matter jurisdiction. The barrier to adjudicating the claim is the inability of a district court in either state to obtain in personam jurisdiction over the other state's custodian. This Comment will now explore various theories by which such in personam jurisdiction might be acquired.

\section{In PERsonam JuRisdiction}

Habeas corpus proceedings are technically civil actions. ${ }^{30}$ They are not, however, automatically subject to all rules or statutes governing such actions. For example, the Supreme Court has held that in view of the history of the writ and the intended scope of the Federal Rules of Civil Procedure a petitioner does not have the right to serve interrogatories on his custodian, although the Federal Rules allow for broad discovery in civil suits. ${ }^{31}$ Likewise, the Court has refused to apply to habeas proceedings a federal statute that provides for nationwide service of process when the defendant is a federal officer or employee. ${ }^{32}$

The Federal Rules are "applicable to proceedings for . . . habeas corpus ... to the extent that the practice in such proceedings is not set forth in statutes of the United States and has heretofore conformed to the practice in civil actions." ${ }^{33}$ Rule 82 states that the Federal Rules "shall not be construed to extend or limit the jurisdiction of the United States district courts . . .,"34 but this provision has been interpreted to refer only to subject matter jurisdiction and not to the manner in which parties are brought before a court. ${ }^{35}$ Accordingly, the Federal Rules may be useful in determining the validity of service of process. ${ }^{36}$ Other

\footnotetext{
${ }^{30}$ R. Sokol, Federal Habeas Corpus $\S 2$ (2d ed. 1969) (collecting cases).

${ }^{31}$ Harris v. Nelson, 394 U.S. 286, 292-98 (1969).

${ }^{32}$ Schlanger v. Seamans, 401 U.S. 487,490 n.4 (1971).

${ }^{33}$ Fed. R. Civ. P. 81(a)(2).

${ }^{34} \mathrm{Id} .82$.

357 J. Moore, Federal Practice If 82.02[1], at 82-83 (2d ed. 1975).

${ }^{36}$ See FED. R. CIv. P. 4; text accompanying notes $42-52$ infra.
}

The applicability of rule 4 to habeas proceedings is technically an open question. See Harris v. Nelson, 394 U.S. 286, 294 n.5 (1969) (although holding that rule 33 does 
limitations on federal district court jurisdiction are delineated in the habeas statutes. Once a court has obtained in personam jurisdiction over the out-of-state custodian, the only additional requirements for habeas relief are that the petitioner be "in custody in violation of the Constitution or laws or treaties of the United States" 37 and that he have exhausted the remedies available in the state courts. ${ }^{38}$

The answer to the threshold question whether process can be served effectively on an out-of-state custodian will depend on whether the petitioner seeks to attack the foreign detainer in the confining state or in the state that issued the detainer.

\section{A. District Court in the Confining State: Service of Process}

In the event that a prisoner petitions for a writ of habeas corpus in a district court located in the state of his confinement, in personam jurisdiction over the custodian of the forum state may be obtained readily. Thus, the court could adjudicate the prisoner's claims that relate to the present impact of a foreign detainer. Because the court in the confining state may be unable to acquire in personam jurisdiction over the out-ofstate custodian, however, the prisoner may be precluded from challenging the validity of the foreign detainer. Although the prisoner is "in custody" of the demanding state, ${ }^{39}$ the out-ofstate custodian, by virtue of his location, is not automatically subject to service of process. ${ }^{40}$ Neverthless, under the Federal

not apply to habeas corpus actions, the Court reserved judgment on the bearing of other rules). But no convincing rationale appears for limiting the purview of rule 4, and courts have assumed its relevance to habeas actions. See Norris v. Georgia, 522 F.2d 1006,1009 n.2 (4th Gir. 1975); Lawrence v. Blackwell, 298 F. Supp. 708, 711 (N.D. Ga. 1969).

Arguably, the statutory requirement that district courts issue habeas writs only "within their respective jurisdictions," 28 U.S.C. § 2241 (a) (1970), supersedes rule 4 and confines courts to serving custodians only within the courts' territorial jurisdictions. See Lee v. United States, 501 F.2d 494 (8th Cir. 1974); Sholars v. Matter, 491 F.2d 279 (9th Cir.), cert. denied, 419 U.S. 970 (1974). But the Supreme Court has functionally defined the "presence" of a custodian within a jurisdiction for habeas purposes as being susceptible to service of process. See Braden v. 30th Judicial Circuit Court, 410 U.S. 484, 495 (1973); Strait v. Laird, 406 U.S. 341, 345 n.2 (1972).

${ }^{37} 28$ U.S.C. $\S \S 2241$ (c)(3), 2254(a) (1970).

${ }^{38} I d$. §§ 2254(b), (c).

${ }^{39}$ See R. SoкоL, supra note 30 , at $\S 6.1$.

${ }^{40}$ The following discussion disregards the possibility that an out-of-state custodian may be served with process while traveling or vacationing within the confining state.

The analysis also proceeds on the assumption that the mere invocation of general equity considerations fails to establish in personam jurisdiction, although such a suggestion has been occasionally advanced. See Word v. North Carolina, 406 F.2d 352, 366 
Rules, ${ }^{41}$ process might be served on the out-of-state custodian in two ways: service upon an agent and service under a longarm statute.

\section{Service upon an Agent}

The Federal Rules provide that service upon an individual other than an infant or incompetent may be made by delivering a copy of the summons and complaint to "an agent authorized by appointment or by law to receive service of process." 42 When a prisoner is subject to a foreign detainer, the actual custodian, by holding the prisoner for the demanding state and placing conditions on his confinement as a result of the detainer, arguably functions as an agent for that state. ${ }^{43}$

The Federal Rules recognize two types of agents who are able to receive service of process: those authorized by appointment and those authorized by law. An agent authorized by appointment is one who is in fact designated to receive service of process. Although such an appaintment may be inferred from surrounding circumstances, the appointment is not proved without a showing that the agent had specific authority, express or implied, to receive service of process. The mere appointment of an agent vested with broad authority is insufficient to establish in personam jurisdiction, ${ }^{44}$ even though the agent actually accepts process or asserts his authority to do so. ${ }^{45}$ Thus, absent authorization of an agent by law, no agency to receive service of process will be acknowledged without a rather clear showing of an appointment of an agent for that purpose. Therefore, even if the actual custodian were considered an agent of the demanding state, service of process upon him would not establish in personam jurisdiction with regard to the demanding state unless the custodian were properly authorized. Research yields no case in which the demanding state has appointed the actual custodian to

(4th Cir. 1969) (Sobeloff, J., concurring in part and dissenting in part) (not specifically addressing the problem of in personam jurisdiction): "When the consequences of a foreign detainer are visited upon a prisoner in the place of detention, fairness to the prisoner demands that the confining state be deemed at least $a$ proper forum, if not the only one, in which to challenge the detainer and the underlying conviction." See also Bedwell v. Harris, 451 F.2d 122 (10th Gir. 1971).

41 See note 36 supra \& accompanying text.

42 FED. R. Grv. P. 4(d)(1).

${ }^{43}$ See Braden v. 30th Judicial Circuit Court, 410 U.S. 484, 498-99 (1973); $c f$. Cleveland v. Ciccone, 517 F.2d 1082, 1085 (8th Cir. 1975); Wilkins v. Erickson, 484 F.2d 969, 973 (8th Cir. 1973).

$442 \mathrm{~J}$. Moore, Federal Practice 1 4.12, at 1049-50 (2d ed. 1975).

${ }^{45} I d$. 4.12 , at 1050-51 \& cases cited therein. 
receive service of process. Arguments that agency exists have relied simply on inference:

I have little doubt but that the detaining North Carolina authority acted as an agent for the two other states. He kept custody of Norris for them as well as for North Carolina. Exacerbated conditions of confinement were inflicted on Norris because of their detainers. Whether or not Georgia or Louisiana intended that effect of their detainers is immaterial. The fact is that by lodging the detainers the two states had continuing and not one-time effects on Norris. The North Carolina custodian did not cause these effects; he was the medium through which they reached Norris. He was, in short, the agent of the states which, through lodging the detainers, affected Norris. ${ }^{46}$

These arguments fail to demonstrate, however, that the actual custodian was authorized by the demanding state to be an agent for the purpose of receiving service of process.

The provision of the Federal Rules that allows service of process upon an agent authorized by law is somewhat ambiguous; whether the authorizing law is the common law, federal law, or state law is unclear. ${ }^{47}$ Reference to the common law might imply an estoppel theory, under which a legal relationship could not be denied by a defendant whose actions suggested an authorization of agency to receive process, on which a plaintiff relied to his detriment. ${ }^{48}$ This estoppel theory would be of no use to a prisoner petitioning for a writ of habeas corpus, however, because the demanding state would not have misled the prisoner to believe that his immediate custodian possessed authority to receive process on behalf of the demanding state. On the contrary, in all probability the demanding state would have continuously denied authorization of agency, from the time it issued the detainer. A prisoner challenging a foreign detainer also could not establish statutory authorization of agency by federal law; federal law simply does not provide that in personam jurisdiction over an out-of-state custodian can be obtained by serving the custodian of the confining state. Similarly, agency to receive process in the context of foreign detainers is generally

${ }^{46}$ Norris v. Georgia, 522 F.2d 1006, 1016 (4th Cir. 1975) (Winter, J., dissenting in part) (footnote omitted).

$472 \mathrm{~J}$. MOORE, supra note 44, If 4.12 , at 1052.

${ }^{48} \mathrm{Id}$. 
not authorized by state law, although states have specifically empowered state officials to receive service of process in other contexts by state long-arm statutes. ${ }^{49}$ State long-arm statutes, however, are precisely the means by which a district court in a confining state may obtain in personam jurisdiction over the custodian of a demanding state.

\section{Service Under a Long-Arm Statute}

The Federal Rules provide that service upon an individual may be made in a manner "prescribed by the law of-the state in which the district court is held for the service of summons or other like process upon any such defendant in an action brought in the courts of general jurisdiction of that state."50 Thus, subject only to due process notions of fair play and substantial justice, ${ }^{51}$ plaintiffs in federal district courts can rely on state statutes that authorize service of process beyond the territorial boundaries of the state. ${ }^{52}$ Such statutes have been developed in a variety of contexts. ${ }^{53}$ For example, states have passed legislation enabling courts to obtain jurisdiction over out-of-state motorists by serving process on a state official, ${ }^{54}$ over foreign insurance companies in suits by policyholders, ${ }^{55}$ and over out-of-state

${ }^{49}$ E.g., Hess v. Pawloski, 274 U.S. 352 (1927); see text accompanying note 54 infra.

${ }^{50}$ FED. R. CIv. P. 4(d)(7). The words "such defendant" in rule 4(d)(7) do not refer specifically to the type of defendant involved here-an out-of-state custodian in a habeas proceeding-but rather to any class of individuals included in rules 4(d)(1)-(3). See also FED. R. CIV. P. 4(e), (f).

${ }^{51}$ See International Shoe Co. v. Washington, 326 U.S. 310,316 (1945).

52 Presently existing long-arm statutes of at least some states are sufficiently broad to encompass the proposed use. For example, Rhode Island claims jurisdiction "in every case not contrary to the provisions of the constitution or laws of the United States." R.I. GEN. Laws ANN. § 9-5-33 (1970). A very similar California provision states: "A court of this state may exercise jurisdiction on any basis not inconsistent with the Constitution of this state or of the United States." CaL. Civ. Pro. Code § 410.10 (West 1973). For discussion of the California statute, see Gorfinkel \& Lavine, Long-Arm Jurisdiction in California Under New Section 410.10 of the Code of Civil Procedure, 21 Hastings L.J. 1163 (1970); Comment, In Personam Jurisdiction: New Horizons in California, 1 PACIFIC L.J. 671 (1970). California's provision has been accepted and explicated by the judiciary. As stated in Threlkeld v. Tucker, 496 F.2d 1101, 1103 (9th Cir. 1974): "The jurisdiction of the California courts is therefore coextensive with the outer limits of due process under the state and federal constitutions, as those limits have been defined by the United States Supreme Court." Accord, Republic Int'l Corp. v. Amco Engrs., Inc., 516 F.2d 161 (9th Cir. 1975).

Note that in Lawrence v. Blackwell, 298 F. Supp. 708, 711 (N.D. Ga. 1969), the court held that Georgia's more specific long-arm statute, GA. CODE ANN. § 24-113.1 (1971), did not enable service of process on an out-of-state custodian.

${ }^{53}$ For a partial compilation of the diverse literature that has arisen on this subject, see J. Cound, J. Friedenthal \& A. Miller, Civil Procedure 99 n.6 (2d ed. 1974).

${ }_{54}$ See, e.g., Hess v. Pawloski, 274 U.S. 352 (1927).

${ }^{55}$ See, e.g., McGee v. International Life Ins. Co., 355 U.S. 220 (1957). 
tortfeasors. ${ }^{56}$ In each case, the application of the statute is conditioned as a matter of due process on the defendant's having established minimum contacts with the forum state and on the claim's being related in some fashion to that state. ${ }^{57}$

The minimum-contacts test was first announced in International Shoe Co. v. Washington.$^{58}$ In that case, the Court held that a foreign corporation was sufficiently "present" in the forum state to allow the exercise of in personam jurisdiction over the corporation only when the corporation had such minimum contacts with the forum state as make it reasonable to require the corporation to defend a suit in that state. ${ }^{59}$ The Court noted that

to the extent that a corporation exercises the privilege of conducting activities within a state, it enjoys the benefits and protection of the laws of that state. The exercise of that privilege may give rise to obligations, and, so far as those obligations arise out of or are connected with the activities within the state, a procedure which requires the corporation to respond to a suit brought to enforce them can, in most instances, hardly be said to be undue. ${ }^{60}$

This rationale was reaffirmed in Travelers Health Association v. Virginia ex rel. State Corp. Commission, ${ }^{61}$ in which the Court recognized a Virginia state commission's in personam jurisdiction over a nonprofit corporation and its treasurer (in his official and personal capacity), whose business activities were conducted primarily in Nebraska because the activities were found to "reach out beyond one state and create continuing relationships and obligations with citizens of another state . . ."62 Travelers has been interpreted as extending the International Shoe doctrine to noncorporate defendants, at least for certain subjects. ${ }^{63}$

The minimum-contacts analysis has proven useful in the context of a serviceman's petitioning for a writ of habeas corpus to escape an allegedly unlawful military command. In Strait $v$. Laird, ${ }^{64}$ a reserve officer petitioned for a writ of habeas corpus in

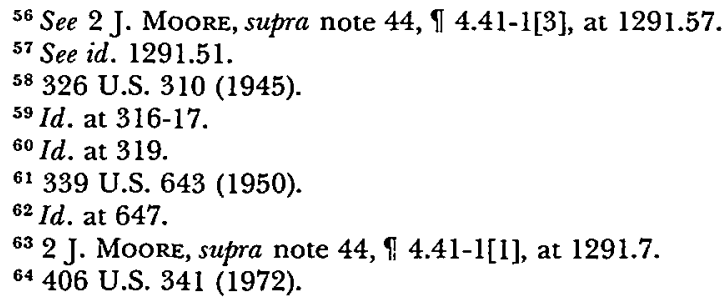


a district court in California following the denial of his application for conscientious objector status. Although the petitioner's nominal commanding officer was in Indiana, the petitioner's only meaningful contact with the army had been in California, and the Court ruled that his commanding officer was constructively present in California through the officers in the service hierarchy who had processed the petitioner's application for discharge. ${ }^{65}$ The Court concluded that this "chain of command" was a sufficient contact to distinguish Strait from an earlier case in which a district court in Arizona was held to lack jurisdiction to entertain a habeas proceeding by an enlisted man whose commanding officer was located in Georgia, because no officer had custody of or command over the petitioner in Arizona. ${ }^{66}$

The chain-of-command theory does not fit precisely the case of a foreign detainer because the response to the detainer by the confining state is based not on command but on cooperation. ${ }^{67}$ In one sense any order received by a soldier emanates from his commanding officer, whether or not some intermediate subordinate actually issues the order. Generally, the commanding officer can theoretically, if not practically, review and change whatever order has been issued. In contrast, a state that has lodged a detainer against a prisoner confined in another state cannot issue any affirmative orders with respect to the prisoner's present status, and indeed it may have no interest in how the detainer affects the prisoner's confinement.

Nevertheless, the contacts between the defendant and the forum state in Strait may have been less substantial than the contacts between the custodian of a state that issues a detainer and the state in which the prisoner who is subject to that detainer is confined. The basis for recognizing in personam jurisdiction in Strait was that the petitioner had established meaningful contacts with the army only in California: he had never visited Indiana, he had been commissioned in California, he had applied for conscientious objector status in California, and he had been in that state when his application was denied. ${ }^{68}$ The record, how-

\section{${ }^{65} I d$. at 345 .}

${ }^{66}$ Schlanger v. Seamans, 401 U.S. 487 (1971).

${ }^{67}$ For certain types of detainers, the cooperation is formalized in the Interstate Agreement on Detainers. See, e.g., Cal. PENaL Code $\$ \S 1389-1389.7$ (West 1970), as amended, $\S \S 1389.7-1389.8$ (West Supp. 1976). This agreement applies only to detainers issued for untried indictments, informations, or complaints. The cooperation thus obtained resembles a contractual relationship with reciprocal rights and obligations attaching to the enactment of the legislation by party states.

${ }^{68} 406$ U.S. at 343. 
ever, failed to establish unequivocally that the petitioner had been subject to any military orders issued by superiors in California ${ }^{69}$ The petitioner's commanding officer, therefore, while exerting influence over the petitioner's actions, may have done so without interacting with or relying on intermediaries in California. Thus, despite the petitioner's extensive contacts with California, the contacts of his commanding officer with that state were slight. The effect of a detainer, on the other hand, is to create a continuing relationship between the prisoner, the confining state, and the demanding state through the cooperative arrangement between the demanding and confining states. Thus, the foreign custodian, by issuing a detainer given present effect in the confining state, ${ }^{70}$ arguably possesses adequate contact with the confining state to make it reasonable to require him to defend a habeas corpus proceeding in that state. ${ }^{71}$

Accordingly, in personam jurisdiction over a foreign custodian might be obtained in a federal district court in the confining state by use of a state long-arm statute. ${ }^{72}$ The prisoner must,

${ }^{69} \mathrm{Id}$. at 347 (Rehnquist, J., dissenting).

${ }^{70} \mathrm{Cf}$. Shelton v. Meier, 485 F.2d 1177, 1178 (9th Cir. 1973) (implying that a federal prisoner cannot attack the validity of a foreign detainer in the confining state without alleging adverse present impact).

${ }^{71}$ But see Lawrence v. Blackwell, 298 F. Supp. 708, 711 (N.D. Ga. 1969) (holding that Georgia's long-arm statute cannot be used to secure service of process on representatives of other states).

Technically, the respondent is not the state, but the custodian: "It is not necessary to name a more important official than is necessary. If the prisoner is confined in a penitentiary, for example, the proper respondent would be the warden, not the Attorney General of the United States." R. SokoL, supra note 30, § 7, at 81. Thus, throughout this Comment the use of the terms "demanding state" and "confining state" should be read as the more precise terms "custodian in the demanding state" and "custodian in the confining state."

${ }^{72}$ It has been recognized that the forum state itself must generally have some legitimate interest in allowing plaintiffs to serve process on out-of-state defendants. Yet aside from the inconvenience and potential unfairness to prisoners if they are forced to petition for a writ in another state, are there any state interests? This question is arguably irrelevant to the jurisdictional issue in habeas proceedings because Strait and the chain-of-command cases have shown no regard for any state interests (reasonably enough, as only federal soldiers had been involved). Thus, a federal prisoner, petitioning for a writ of habeas corpus to challenge the validity of a foreign detainer, probably would not have to aver any state interest to justify using the state's long-arm statute. In other contexts, the inequity of treating state and federal prisoners differently for habeas purposes has been recognized, see Kaufman v. United States, 394 U.S. 217, 225-26 (1969), and likewise in this context there is no justification for separate treatment. Thus the due process question can be limited to a determination of the proper usage of the statute.

Of course, due process requires that adequate notice be given the foreign custodian. In International Shoe (in the context of a corporate defendant), the Court indicated that either substituted service on some person within the forum state or service on the defendant by mail at the defendant's home office might be proper. 326 U.S. 310,320 
however, have exhausted his state remedies. Because he would be attacking both the validity and the effect of a detainer, and thereby litigating against two different states, the prisoner must have fully pursued relief in each state, exactly as though he were bringing two separate actions. ${ }^{73}$

\section{B. District Court in the Demanding State: Service of Process}

A federal district court in a state that has lodged a detainer against a prisoner in another state has in personam jurisdiction over the custodian in the forum state and may consequently adjudicate the prisoner's claims relating to the validity of the warrant, indictment, or conviction underlying the detainer. In the interests of judicial efficiency and fairness to the prisoner, the same court ought to be able to determine claims concerning the detainer's present impact on the prisoner in the confining state. The theories discussed above, however, do not even arguably provide a means of obtaining in personam jurisdiction over the custodian in the confining state. Neither agency principles nor a long-arm statute can be used here effectively.

As already detailed, an agent can be authorized to receive service of process by either appointment or law. ${ }^{74}$ Rarely, if ever, will an agent be appointed by the confining state to receive service of process in the demanding state. Nor is there any manner in which to establish authorization of an agent by law.

The lack of any activity in the demanding state by the confining state negates the possibility of employing a long-arm statute to obtain jurisdiction over the immediate custodian. The minimum-contacts test cannot be met. $^{75}$ In contrast to the demanding state's connection with the confining state, in which a structure similar to the army's chain of command links the issuer of the detainer to the immediate custodian, no such relationship

(1945). Indeed, service is satisfactory as long as there is a reasonable assurance that actual notice will occur. Id.

${ }^{73}$ Braden v. 30th Judicial Circuit Court, 410 U.S. 484 (1973) (held, the prisoner must have exhausted remedies in the demanding state related to the validity of the detainer); Nelson v. George, 399 U.S. 224 (1970) (held, the prisoner must have exhausted remedies in the confining state related to the present effect of the detainer).

${ }^{74}$ See text accompanying notes $42-48$ supra.

${ }^{75}$ Certain contracts may exist, but not at the time a prisoner would bring a habeas action. Specifically, at or near the conclusion of the prisoner's incarceration in the confining state, steps may be taken by his immediate custodian to ensure the surrender of the prisoner to the demanding state. This action might conceivably constitute sufficient minimum contacts, but it transpires well after the time the prisoner might desire to attack the validity of the detainer. 
exists here. It could be argued that any command structure that connects the demanding state to the confining state should operate just as well in the reverse direction. Were there a formal command structure, this argument might have some force for the actions of the subordinate would in a sense be determined as soon as the commander issued orders. Thus, the subordinate would be constructively present wherever the commander was present. No such formal command structure exists, however, between the confining and demanding states. Consequently, although the demanding state-having lodged a detainer against a prisoner in the confining state, and thereby having initiated a relationship with the confining state, possibly resulting in changes in the conditions of the prisoner's immediate confinement-may have sufficient contacts with the confining state to satisfy the minimum-contacts test, the confining state lacks such minimum contacts with the demanding state.

In summary, the arguments that can be employed successfully to establish the joint jurisdiction necessary to the adjudication of the validity and impact of a detainer in the confining jurisdiction cannot be used to establish similar jurisdiction in the demanding state.

\section{Venue and Considerations of Convenience}

Under the federal habeas statutes and the Federal Rules of Civil Procedure, a federal district court in a habeas proceeding in the confining state has jurisdiction over the custodians of the demanding and confining states, and may therefore decide claims relating to both the validity and the present impact of a foreign detainer. On the other hand, a district court in the demanding state has in personam jurisdiction only over the custodian of the forum state, and can thus determine only claims relating to the validity of the detainer. Consequently, judicial efficiency is maximized if the prisoner petitions in the confining state. A district court in the confining state, however, may not always be the most convenient forum in which to proceed. Whether a district court in the confining state is a more convenient forum than a district court in the demanding state may depend upon whether the habeas proceeding involves an examination of trial proceedings, pretrial events, or post-trial events. The nature of the habeas proceeding is determined in turn by whether the challenged detainer was issued for a parole violation, a conviction, an indictment, or merely an arrest warrant.

In the case of a detainer based on an arrest warrant, the 
only question raised in a habeas action might be whether there was probable cause to arrest, the determination of which may entail only the examination of the contents of an affidavit. A hearing involving witnesses may be unnecessary. Similarly, if an indictment underlies a detainer and the prisoner is claiming his right to a speedy trial, a record containing all relevant judicial administrative decisions might be stipulated. Consequently, in certain cases scant reason may exist not to adjudicate the effect and validity of a foreign detainer in a single action. ${ }^{76}$

When the detainer is based on a conviction that has survived the prisoner's state-provided post-conviction collateral attacks, any nonfrivolous claim requiring an evidentiary hearing will probably necessitate the production of a number of witnesses, perhaps including opposing counsel and the presiding judge from the original trial. ${ }^{77}$ In addition, because the judgment of the demanding state would be challenged in the habeas proceeding, a court situated in that state would be more familiar with any aspects of state law that might arise in the hearing. ${ }^{78}$ Also, necessary records would be easily accessible by a court in the demanding state. On the other hand, if the habeas action were maintained in the demanding state, pretrial conferences between the petitioner and his counsel might be precluded as a practical matter. The court in Word, however, in rejecting this argument against maintaining the action in the demanding state, noted that no major problems had arisen in the analogous situation of federal prisoners' seeking post-conviction relief in sentencing courts not located in the districts of confinement. ${ }^{79}$

Thus, on balance, when a detainer is based on a conviction, the difficulties inherent in transporting what may be a large number of people to the confining state, the familiarity of a court in the demanding state with the relevant state law, and the availability of necessary records may outweigh the burden of transporting the prisoner to the demanding state (including the risk of escape ${ }^{80}$ ) and the unfairness to the prisoner of his having to bring two actions instead of one. Thus, a district court in the

${ }^{76}$ See Norris v. Georgia, 357 F. Supp. 1200, 1204 (W.D.N.C. 1973), aff'd in part, rev'd in part, 522 F.2d 1006 (4th Cir. 1975). The same may be true when a parole violation underlies a detainer. $C f$. Dillworth v. Barker, 465 F.2d 1138, 1341 (5th Cir. 1972).

${ }^{77}$ See Word v. North Carolina, 406 F.2d 352, 356 (4th Cir. 1969).

${ }^{78}$ See Braden v. 30th Judicial Circuit Court, 410 U.S. 484, 499 (1973).

${ }^{79}$ Word v. North Carolina, 406 F.2d 352, 357 (4th Cir. 1969).

${ }^{80}$ See generally Braden v. 30th Judicial Circuit Court, 410 U.S. 484, 501 (1973) (Blackmun, J., concurring). 
demanding state may be the more convenient forum for adjudicating a challenge to the validity of the detainer. ${ }^{81}$ In fact, were jurisdiction exercised routinely by a court in the confining state, witnesses, counsel, and records located in the demanding state might often be subject to court orders to appear in another state. Such a result might impede the effective utilization of detainers.

In certain situations, however, fairness demands that the prisoner be able to attack the validity of a detainer in the state of his confinement, as when the prisoner is seriously ill and cannot be transported any distance, or when the prisoner can demonstrate that he would be prejudiced in the district court in the demanding state. When more than one foreign detainer is involved, as in Norris $v$. Georgia, ${ }^{82}$ fairness might call for the same resolution.

Recognizing that considerations of convenience may on occasion dictate that a challenge to the validity of a detainer be heard in the demanding state does not necessarily vitiate the effect of holding that the confining state has in personam jurisdiction over the foreign custodian and thus has the ability to entertain a challenge to the validity of the detainer. Assuming such jurisdiction exists, a prisoner who desires to challenge both the validity and the impact of a foreign detainer may petition initially a district court in the confining state. Then, if considerations of convenience so require, the court may transfer the habeas proceeding, insofar as it relates to the validity of the detainer, to a district court in the demanding state. ${ }^{83}$ At the same time, the district court in the confining state can retain jurisdiction over claims relating to the present effects of the detainer, so that such claims can be adjudicated once the validity of the detainer has been determined. ${ }^{84}$ In this way, a prisoner is not forced to initiate two separate actions, and he avoids the dangers accompanying split litigation alluded to earlier, ${ }^{85}$ such as the confining state's not being subject to a decision by the demand-

${ }^{81}$ See id. at 494.

82522 F.2d 1006 (4th Cir. 1975).

${ }^{83}$ See Hoffman v. Blaski, 363 U.S. 335 (1960); 28 U.S.C. \$ 1404(a) (1970). For a discussion of long-arm statutes and the forum non conveniens rationale, see Casad, Long Arm and Convenient Forum, 20 U. KAN. L. Rev. 1 (1971); Morley, Forum Non Conveniens: Restraining Long-Arm Jurisdiction, 68 Nw. U.L. Rev. 24 (1973).

${ }^{84}$ The court may order separate trials of any claims or issues. FED. R. CIv. P. 42(b). If, however, the adjudication of the detainer's validity and effects involves common elements, or could be accomplished more conveniently and fairly in a single proceeding, the court may decide not to order separate actions.

${ }^{85}$ See text accompanying notes $27-28$ supra. 
ing state invalidating the detainer. Thus, the district court in the confining state will be able to select the forum most convenient for the litigation, while ensuring that basic considerations of fairness to the prisoner are respected.

\section{ConCLUSION}

A state prisoner whose confinement is affected by an outof-state detainer will confront jurisdictional difficulties if he attempts to challenge the validity and effect of the detainer in a single federal habeas proceeding. Due to the absence of any activity by the confining state in the demanding state, a district court in the demanding state cannot obtain in personam jurisdiction over the prisoner's immediate custodian. Consequently, a court in the demanding state cannot entertain claims relating to the present impact of the detainer. Most courts have ruled that a district court in the confining state is without jurisdiction over the prisoner's foreign custodian and is thus unable to adjudicate claims relating to the validity of the detainer. Nevertheless, relying on a theory similar to that employed successfully by soldiers seeking release from unlawful military commands, a prisoner might use the confining state's long-arm statute to serve process on his foreign custodian, thereby enabling a court in the confining state to determine claims relating to both the effect and validity of the detainer. The district court in the confining state can then, if necessary for practical reasons, transfer to a district court in the demanding state claims concerning the validity of the detainer, while retaining jurisdiction over claims relating to the effect of the detainer. By this procedure, the interests of fairness and judicial efficiency would be furthered. 
